\title{
Die lewensbeskouing van D.F. Malan (1874-1959) soos weerspieël in openbare standpunte
}

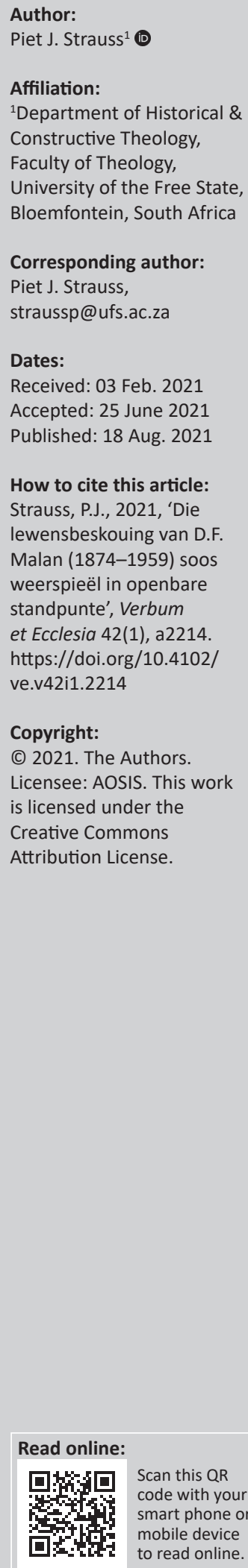

The world view of D.F. Malan as reflected in his public stance. D.F. Malan was born in 1874 and grew up on a farm near Riebeeck-Wes in the Western Cape. He died in 1959 in Stellenbosch. Malan started his career as a minister in the Dutch Reformed Church. Before that he regarded himself as a student in Theology with a vocation. In 1905 he became a Doctor in Theology at the University of Utrecht in the Netherlands. He entered politics in June 1915 by becoming the first editor of the new Dutch-Afrikaans newspaper, De Burger, and at the same time, the leader of the National Party (founded in 1914) in the Cape Province. Malan had a career in politics for almost 40 years. He retired as the Prime Minister of South Africa in 1954. In his time Malan concentrated especially on unity among the Afrikaners in culture and politics, the cooperation between Afrikaans- and English-speaking citizens, and the well-being of all the people in South Africa. As a reformed Christian in every sphere of life, Malan believed in God-given principles and a timely application of this by believers. This worldview of his became known through his preaching, speeches, articles and commentaries on matters. His worldview influenced his approach to politics and the cultural aspect of his existence. The purpose of this article is to explain this view by using primary sources. The main figure in this article was a minister in the Dutch Reformed Church with a noticeable influence in the affairs of the church, and he was also a South African politician on national level. These aspects influenced the history of the church, as well as the political or general history of South Africa. It also made an imprint on church political concepts and ethical considerations that had to come to grips with Malan leaving the church ministry for politics, as well as the ethics of policies like apartheid and the political unity of an officially bilingual Union of South Africa. For Malan, his worldview determined his aims in politics, namely the cultural unity among Afrikaners, while they and their English-speaking counterparts form a successful state, and the relationship between all South Africans.

Intradisciplinary and/or interdisciplinary implications: The interdisciplinary implications of this article involved the subjects of church history, general history and a political ethics approach.

Keywords: D.F. Malan; Dutch Reformed Church; Prime Minister of South Africa; all-inclusive Christian worldview; Neo-Calvinistic; unity of culture among Afrikaners; unity of Englishand Afrikaans-speaking citizens; Apartheid with white guardianship and happiness for all inhabitants.

\section{Inleiding}

Daniël Francois Malan was die vierde Eerste Minister (1948-1954) van die Unie van Suid-Afrika (1910-1961). Sy premierskap span die kroon op 'n openbare politieke loopbaan van bykans 40 jaar. Op 13 Junie 1915 lewer hy sy afskeidspreek as predikant van die NG Kerk Graaff-Reinet, om die redakteur van die nuwe Hollands-Afrikaanse Dagblad, De Burger, in Kaapstad te word. ${ }^{1}$ By 'n konferensie op Cradock in Junie 1915, word die redakteurskap met die leierskap van die Nasionale Party (NP) in Kaapland in Malan as persoon verenig. Die 41-jarige NG predikant begewe hom nou in die vaarwater van die SuidAfrikaanse politiek. Nadat hy in 1915 in Cradock en in 1917 in Victoria-Wes misluk, word Malan in 1919 tot lid van die Volksraad vir Calvinia verkies. Op 30 November 1954 tree hy as 'n 80-jarige uit as Eerste Minister. Malan word op 22 Mei 1874 op die plaas Allesverloren naby

1.Afskeidspreek opgeneem in S.W. Pienaar se bundel van openbare toesprake van D.F. Malan. Pienaar publiseer dit in 1964 : Glo in u volk - D.F. Malan as redenaar, Kaapstad: Tafelberg, bl. 9-18. Pienaar se titel kom uit die toespraak van Malan op 2 Mei 1937 op De Houtplaas by Bellspas naby Winburg, waar Piet Retief as goewerneur van die Voortrekkers ' $n$ eeu vroeër ingehuldig is (De Jongh 1987:109). Hier gee Malan die spreuk waarvoor hy by baie mense bekend was: 'Glo in God, glo in u volk, glo in jouself'. Dit was' $n$ leuse wat die inhoud van sy basiese oortuigings en eie verstaan van sy lewens- en openbare roeping reflekteer (Pienaar 1964:234-238). 
Riebeek-Wes in die Wes-Kaap gebore, en sterf op 7 Februarie 1959 op Stellenbosch (Booyens 1977:577, 579; Pienaar 1964:9).

'n Biograaf H.B. Thom, noem Malan die produk van 'n boereplaas wat die 'dissipline, strewe en lewenswyse ... van die boerehuis geken het'. 'n Man met 'n weetgierige gees wat studie met albei hande aangegryp het (Thom 1980:346-347). Daarom verlaat hy Suid-Afrika in September 1900 vir nagraadse teologiese studie in Utrecht, Nederland. Daar promoveer hy in die Godgeleerdheid op 20 Januarie 1905 met 'n proefskrif getiteld, Het idealisme van Berkeley (Booyens 1969:95, 107; 1977:578). Volgens Booyens - hierdie uitspraak is egter 'n verskraling! - het Malan sy lewe aan die studie van die teologie en die staatkunde gewy. Die vrug daarvan het "n wesentlike invloed op sy lewensbeskouing en loopbaan' gehad (Booyens 1977:584). Wat egter vir hierdie artikel van belang is, is die beweerde verband tussen sy studie en sy lewensbeskouing. Thom (1980) noem Malan nie 'n avonturier nie, maar iemand met 'n ernstige en oortuigde lewensopvatting wat 'stip eerlik' methomself was. Hy het hom by mense wat lewensbeskoulik, geestelik en sosiaal die naaste aan hom was, die ChristenAfrikaners, geskaar om hulle te help ten tyde van geestelike en materiële verbrokkeling, tweedrag en verarming. Vanuit 'n roeping deur die Here God (dit hou verband met die woorde glo in God in sy leuse van 1937), wou hy hulle bystaan om hulle selfrespek te behou ('n verband met glo in jouself in sy leuse) en 'n sinvolle politieke inset in SuidAfrika te maak ('n verband met glo in $u$ volk in sy leuse). As Eerste Minister het hy hom vir 'n sosiale en staatkundige orde in die Unie beywer, wat vir alle 'vername bevolkingsgroepe ... deug' en die meeste algemene geluk kon bring. Hiervoor het hy die woord 'apartheid', syns insiens 'n paslike Afrikaanse uitdrukking, gebruik. Vir hom was apartheid nie 'n konstante beginsel nie, maar 'n werksmetode. Hierna word later teruggekom.

Malan het vaste beginsels gehad wat koers aan sy lewe gegee het, en 'n onderskeid tussen beginsels en die toepassing of uitlewing daarvan gemaak het. Beginsels as bybelgebaseerde lewenskonstantes moes ongeskonde toegepas en uitgeleef word. Metodes of die toepassing, kon na gelang van omstandighede verander of heroorweeg word. Metodes was volgens hom nie konstant nie en mag nie met die status van beginsels verwar word nie (Thom 1980:347).

Malan se oë en gestel was nooit sterk nie, sodat hy nie veel trek vir sosiale plesier en sport gehad het nie. Hy was egter geseën met 'n goeie humorsin, 'n helder verstand en redeneervermoë. As student het hy graag in die natuur gestap en oor sake gedebatteer (Booyens 1977:577). Hierdie eienskappe het gepaard gegaan met pligsgetrouheid en deursettingsvermoë. Erns van oortuiging en deeglikheid het hom genoop om van sy studentedae af nié 'n ding te sê indien hy nie oortuig was dat hy $100 \%$ reg is nie. 'n Studentemaat, die latere prof. G.G. Cillié, bestempel hom as 'n ernstige denker wat kon sê wat hy dink. Hy was rustig en indringend van gees én kon konsepte verstaanbaar oordra (Thom 1980:9, 347).
Ten opsigte van D.F. Malan as redenaar,'n eienskap waarvoor hy onthou sal word, beweer die ervare Afrikaanse joernalis Schalk Pienaar dat Malan se toesprake 'n verslaggewer se droom was. Daarom kon Pienaar sy bundel versamelde Malan-toesprake as skriftelike weergawes of harde kopieë van die oorspronklike, met opgewonde ywer aanpak. Pienaar (1964) vertel:

$[H] y$ het stadig gepraat, honderd en twintig woorde per minuut. Hy het sy sinne voltooi, en sy gedagtes. Maar belangrikste van alles, hy het gedagtes gehad, glashelder, wat logies in mekaar gevloei het, van die eerste begin tot die laaste einde, sodat die gelewerde toespraak soos 'n gemesselde muur daar gestaan het .... (bl. 1)

Bun Booyens (1977) oordeel dat Malan oor die gawe van welsprekendheid beskik het. Hy stel dit soos volg:

[S]y diep sonore stem, deeglike voorbereiding, logiese redenering, oortuigingskrag en indrukwekkende verhoogpersoonlikheid het daartoe bygedra om hom tot een van die grootste redenaars in die Suid-Afrikaanse parlementêre geskiedenis te verhef. (bl. 584)

D.F. Malan se voltooide toesprake - én openbare standpunte het soos 'n gemesselde muur gestaan: dit op sigself leen sy standpunte tot ' $n$ makliker ontleding.

Hierdie artikel ondersoek die lewensbeskoulike of beginselkante van 'n greep uit Malan se openbare standpunte. Sy standpunte het voorgekom in gerapporteerde preke, toesprake, verklarings en menings by instansies en geleenthede waarby hy betrokke was. Daar word op sy rol as predikant, volksleier en politikus gekonsentreer. Die metode is 'n literatuurstudie van grepe vanuit sy lewe. Dit is grepe wat nie noodwendig kronologies nie, maar tematies by mekaar aansluit. Twee primêre bronne was besonder nuttig in hierdie verband, naamlik Malan se outobiografie, Afrikanervolkseenheid en my ervarings op die pad daarheen (1959), en Pienaar se bundel saamgestelde Malantoesprake, Glo in u volk (1964).

Vanweë die omstandighede het Malan in sy tyd op die polities kulturele eenheid en voortbestaan van die Afrikaner gekonsentreer, ${ }^{2}$ die rol van hierdie groep in 'n staatkundige Suid-Afrika, die Afrikaner se bestaan saam met Engelssprekendes en ander kultuurgroepe in die land, met hom in 'n bepalende rol wat staatswette en -strukture betref, asook Malan as 'n Christengelowige en voormalige NG predikant. Daar word ook na die agtergrond van standpunte van Malan gekyk en dit wat hom kon beïnvloed het daartoe.

\section{Invloede op 'n ernstige student}

Daar is gewys op Malan se herkoms as 'n plaasseun uit Riebeeck-Wes: hy het grootgeword in 'n positiewe Afrikaanse gesin, NG Christene, in die laaste dekades van die 19e eeu. Daar is ook gewys op sekere karaktertrekke en ingesteldhede

2.Let op die titel van Malan se outobiografie uit 1959: Afrikaner volkseenheid en my ervarings op die pad daarheen. Booyens en Koorts oordeel dat Malan 'n ervarings op die pad daarheen. Booyens en Koorts oordeel dat Malan ' $n$
pleitbesorger vir die Afrikaanse kultuur en Afrikanernasionalisme was (vgl Booyens pleitbesorger vir die Afrik
1977:584; Koorts 2014). 
van die jong Malan. Sake wat hom vir sy latere lewe toegerus het, is sy deeglikheid, rustigheid, verhoogpersoonlikheid en redeneervermoë (Booyens 1969:320-321).

Drie invloede of sake sou 'n sleutelrol in die vorming van sy lewensbeskouing of benadering tot sake speel: sy geloofsoortuigings en opvoeding, sy teologiese opleiding en die denke van daardie Afrikaners én nie-Afrikaners met wie hy prinsipieel geestelik geassosieer het.

As 'n student aan die teologiese kweekskool op Stellenbosch, het Malan onder die invloed van die lewensvoorbeeld en voordragte van prof. N.J. Hofmeyr gekom: Christelik evangelies en Hollands-Afrikaans. In Nederland beïndruk prof. J.J.P. Valeton hom. Valeton volg die etiese rigting in kerk en teologie wat die Bybel as ' $n$ historiese gegewe in ' $n$ bepaalde konteks beskou. 'n Bron wat met die histories kritiese metode uitgelê moet word. Hierdie houding bring hom in botsing met die destydse kampioen van die 'enger' gereformeerde teologie in Nederland soos bedryf aan die Vrije Universiteit in Amsterdam (VU), Abraham Kuyper. ${ }^{3}$ Kuyper was, naas ander groot inisiatiewe, die inisieerder en medestigter van die VU in 1880 en minister-president van Nederland vanaf 1901-1905 (Strauss 2008:634). Die VU was destyds ' $n$ aantreklike vesting in die gereformeerde teologie vir nagraadse studente uit Suid-Afrika: uit die NG Kerk en veral die Gereformeerde Kerke in SuidAfrika (GKSA). ${ }^{4}$ Vir hulle was die VU aanlokliker as Utrecht. Die gevolg is 'n geestelike verwydering tussen Malan en die neo-Calvinisme van Kuyper, ${ }^{5}$ met sy invloed op dominante pro-apartheidsteoloë in beide kerke, en die lyne van kerkwees in die GKSA (Dopperkerk) (Booyens 1977:577-578; Koorts 2014:57; Odendaal 1957:281; Strauss 2015:32-37). ${ }^{6}$ So 'n verwydering hang Malan om strategiese redes nooit aan die groot kloknie. Dit verhoed hom nie om soos'n neo-Calvinistiese Afrikaner met 'n eie Christelik lewensbeskoulike begronding vir apartheid (soos hy dit by voorkeur genoem het) te kom nie (Strauss 1983:22-23).

3.Koorts gebruik'n onverstaanbare styl met havr-gebrekkig ingeligte? - onvanpaste .Koort gebrik 'n onverstaanbare styl met haar - gebrekkig ingeligte? - onvanpaste en ongemotiveerd het' (Koorts 2014:57, my kursivering, PJS). Dit is' 'n nie-akademiese vertekening van Kuyper en die 20ste-eeuse Christelik reformatoriese of neo-Calvinistiese aanpak van die saak.

4.Vanaf 1907 tot 1952 skryf 60 predikante uit die NG Kerk, meestal nagraads, aan die VU in. Van die 20 teologiese professore wat vanaf 1859 tot 1952 in die NG Kerk dien, studeer 10 aan die VU: almal ná 1907. Die VU vervang Utrecht in die eerste helfte van die 20ste eeu as die gewildste plek in die buiteland vir die nagraadse studie van NG-predikante. Hoewel almal sekerlik nie ewe veel deur Kuyper beïnvloed is nie, toon hierdie stroom ten minste sterk simpatie in die NG Kerk vir die neo-Calvinisme van Kuyper en kie in hierdie tyd (Odendaal 1957:252; Strauss 1994:204-208; 2010:125-130).

5.Die neo-Calvinisme is ' $n$ tendens om Johannes Calvyn (1509-1564) in 'n nuwe 5.Die neo-Calvinisme is " $n$ tendens om Johannes Calvyn (1509-1564) in " $n$ nuwe denke. Die neo-Calvinisme is nie ' $n$ tendens van homogene denke nie, maar verskillende standpunte wat een gemeenskaplike noemer het: dit probeer verskillende standpunte wat by hierdie hervormer of aspekte van sy erfenis in 'n nuwe era en situasie aansluit by hierdie hervormer of aspekte van sy erfenis in 'n nuwe era en situasie
(Strauss 2008:157-159). Die Nederlandse gereformeerde Abraham Kuyper
(1837-1920) word in sekere kringe as 'n buitelandse teoloog uitgewys uit wie se (1837-1920) word in sekere kringe as 'n buitelandse teoloog uitgewys uit wie se neo-Calvinistiese nalatenskap, Afrikaanse apartheidsteoloë geput het vir die begronding van hulle saak (Strauss 1994:203-208)

6.Koorts beweer dat Malan hoër kritiek beoefen het, sonder dat sy ' $\mathrm{n}$ konkrete voorbeeld gee. Dit sou hom dan van die 'Dopper-volgelinge' van Kuyper onderskei (Koorts 2014:57). Sy beweeg hiermee op 'n terrein waaroor sy klaarblyklik nie behoorlik ingelig is nie, en gebruik deurgaans nié die amptelike naam van die behoorlik 'ingelig is nie, en gebruik deurgaans nie die amptelike naam van die destydse 'Gereformeerde Kerk in Suid-Afrika' nie, maar die spotnaam 'Doppers'. By implikasie sou Malan gevolglik simpatiekgesind teenoor Johannes du Plessis in die bekende (of is dit dalk berugte?) Du Plessis-saak van die 1930's moes wees. Koorts verwys na hierdie saak sonder om Malan se persoonlike posisie te verklaar - terwy sy juis oor hom skryf! Sy bly in gebreke om bekend te maak of hy hom hoegenaamd oor hierdie saak uitgelaat het. Om Malan so aan die hoër kritiek uit te lewer, is op sy minste omstrede.
Terwyl D.F. Malan in Nederland vertoef, maak sekere figure 'n groot indruk op hom. Hierdie indrukke sou sy innerlike dryfvere en nasionale oortuigings blootlê én versterk. Die indrukke vind in dié Afrikaanse nagraadse teologiese student uit Suid-Afrika 'n vrugbare teelaarde. Hieronder tel die ortodokse Nederlandse teoloog en digter Nicolaas Beets en die deputasie van drie Boeregeneraals, Louis Botha, Christiaan de Wet en Koos de la Rey, om geld vir verarmde Afrikaners in Europa in te samel na afloop van die AngloBoereoorlog (ABO) in Mei 1902. Die deputasie besoek die bejaarde (bekende Dopper) President Paul Kruger met sy verjaardag op 10 Oktober 1902 in Utrecht waarheen Malan ook genooi word. Dan besoek Malan ook vir President en mevrou M.T. Steyn (Booyens 1969:320). Steyn is in Europa vir behandeling vir 'n spierverlamming wat hy in die oorlog opgedoen het. Malan besoek die Steyns gereeld. Tussen hulle ontstaan daar vanweë gemeenskaplike grondoortuigings, 'n hegte vriendskap. Malan word deur Steyn in Europa en later in Suid-Afrika ten opsigte van sy beskouinge oor politiek en kultuur, volgens Booyens wesenlik beïnvloed. Hierdie invloed geskied aan die begin van Malan se kerklike en politieke loopbaan, omdat Steyn op 28 November 1916 sterf (Booyens 1977:578; Van der Merwe 1921:348-352).

In April 1904 rig Malan twee briewe aan die Nieuwe Rotterdamse Courant waarin hy Afrikaans en Afrikanereenheid - twee sake wat hom deur die loop van sy lewe naby aan die hart lêbestempel as waarborge teen verengelsing. Op kenmerkende wyse en met hierdie sake nog sluimerend, ontwikkel Malan alreeds gedagtes waardeur hy sy vermoë om te kan formuleer, illustreer. Boonop toon hy reeds in 1904 op bykans 30-jarige ouderdom, 'n rype insig in die probleme waarmee die Afrikaner en Suid-Afrika worstel (Booyens 1977:578).

Malan verbind sy leuse van Glo in God, glo in jou volk en glo in jouself uit Winburg in 1937, ook aan die Gelofte van 16 Desember en 'n roepingsbewustheid by die Afrikaners, individueel en as ' $n$ groep. Uit sy lewensoortuiging en die Afrikaner se aanvaarding van die Gelofte van 1838, blyk dit dat hierdie volk as 'n Christelike volk met 'n Christelike lewensroeping geken wil wees. Saamgevat, verbind die Gelofte hulle dus aan die uitleef van Christelike lewenswaardes (Straus 2021:8). Met die aflê van die Gelofte van 1838, het hierdie volk hom aan 'daardie ... lewensrigting verbind' (Malan 1959:239-240). Vir Malan sê of impliseer sy leuse: die volk waaroor dit hier gaan, wil konsekwent Christelik in sy benadering tot die volle lewe wees.

\section{Of jy nou eet of drink, doen alles tot eer van God}

Malan se afskeidspreek op Graaff-Reinet op 13 Junie 1915 by sy verandering van lewenstaat - van die kansel tot die politieke kateder - gee sy visie op 'n Christelike beskouing van die hele lewe weer. Teen die agtergrond van dit wat reeds gesê is, moes hy die rede vir sy verandering aantoon, naamlik dat die predikant én die politikus deur God geroep is. Hy wou 'n loopbaanverandering maak, maar as 'n konsekwente Christen steeds in God se wêreld en in diens van God wil wees. 
Die titel van Malan se afskeidspreek is tipies van hom: 'Dan kom ek om ...' (Pienaar 1964:9-18). Hy vertrek as predikant immers met dit wat in sy leuse van 1937 staan: geloof in God, geloof in sy mense of volk en geloof in homself, of anders gesê, hy vertrek in sy geroepenheid deur die Here. Hy is 'n blote werktuig in die rigting wat deur God bepaal word. Daarom dra die preek 'n bedekte kreet van vertroue in sy opskrif, 'n kreet van vertroue in die nuwe, vreemde omgewing: ek sal doen wat die Here vra - al kom ek ook om. Dis dieselfde houding wat sy geesgenoot, M.T. Steyn, op die Vrouemonument na die dood van 26370 vroue en kinders laat aanbring het: $U$ wil geschiede ... (Van Schoor 1993:2). ${ }^{7}$ Beide Steyn en Malan glo onwrikbaar in die voorsienige God.

Die onderskeid tussen beginsel en toepassing by Malan is reeds in sy eerste sin aanwesig. Die NG Kerk Graaff-Reinet moet weet dat hulle 'voortaan' 'n ander leraar sal hê. 'n Leraar met dieselfde boodskap, maar ' $n$ ander persoonlikheid en 'n ander 'invloed'.

Malan wil voortgaan om op 'n, vir hom, onbeproefde weg, 'ons volk en kerk' en daarmee die Here te dien. Hy verruil die predikantsbediening vir die koerant (Pienaar 1964:9).

Sy teks is 1 Korintiërs 10:31 se woorde: 'Of julle dan eet of drink of enigiets doen, doen alles tot verheerliking van God'. Malan is nie ' $n$ ingeskrewe Dopper nie en volgens sommige mense nie 'n neo-Calvinis nie, maar hy kies 'n teks wat hy uit Calvyn se Institusie sou kon motiveer (Sizoo II sa:448). Hy gee drie hoofgedagtes: nie net die kerk nie, maar ook die nasionaal politieke lewe staan onder die heerskappy van die Here: deur besondere omstandighede kan God ons roep om Hom buite die kerk te dien; en God moet ook in die nasionale lewe verheerlik word (Pienaar 1964:11).

Malan wys die Roomse houding af, naamlik dat die kerk heilig is en die res onheilig; ook dat genade teenoor die natuur staan. Dit is 'n Roomse vertrekpunt dat jy in die kerk die Here dien, maar in die res, die wêreld. Vir hom is kerk en staat inrigtings wat elkeen sy eie opdrag van God ontvang het en met hierdie taak in diens van God moet staan. Die staat mag nooit 'n blote werktuig van die kerk word en omgekeerd nie. Die volk moet in kerk en staat met God rekening hou en Hom dien. Die volk moet met sy 'ganse volkslewe in al sy vertakkinge voor die aangesig van God staan'. God moet as die groot Koning aan wie alles behoort, in heiden- en Christenland heers: in die stoflike dinge 'van die volk, in sy letterkunde en wetenskap', in sy politiek en kerk, sodat God alles in almal kan wees. Anders gestel: die Here moet in die algemene volkslewe - hierdie term gebruik Malan soms vir Afrikaners as 'n kultuurgroep, en soms vir die samelewing of staatsvolk - op alle gebiede gedien word. Die tweeterreine-leer druis volgens Malan in teen 'die gereformeerde opvatting van Gods Woord, waaraan ons vashou ...' (Pienaar 1964:12).

Twee waarnemings blyk oor hierdie houding van D.F. Malan. 7.Resente navorsing dui daarop dat hierdie getal sterftes eerder 34051 was (Raath 2012:13; Reynolds 2013:122).

\section{Malan 'n Calvinis in die breë sin van die woord}

Die eerste is dat beide Calvyn en Kuyper, met 'n enkele wysiging of twee, waarskynlik 'ja en amen' op hierdie punte sou kon sê. God kan én moet op alle terreine gedien word, en aan elke terrein is daar ' $n$ bepaalde taak gegee waardeur hy sy unieke insette in die gemeenskap moet lewer.

Die tweede is dat Malan soos sommige neo-Calvinistiese Afrikaners, byna nasionaal-sosialisties die volk die omvattende, bepalende samelewingskring maak waaraan die ander kringe as vertakkinge behoort, en aan wie hulle by implikasie gebonde is, en selfs onderworpe is. Lewenskringe moet in hulle samestelling hulle deelwees van die volk vertoon. Per konsekwensie moet die volkswil dus in plaas van Gods se wil in die kerk, die staat en die samelewing in hierdie omstandighede geld, omdat die volk verabsoluteer word en vir die samelewing besluit. Hierdie stelling geld omdat die gemeentevergadering of demokratiese meerderheid, kortom die 'volkswil', die eerste en die laaste sê in die kerk het. Behalwe die Christelike geloof, móét volkswees deel uitmaak van die vereistes vir kerklidmaatskap, van die vereistes vir die wat kwalifiseer om regverdig deur die owerheid behandel word of vir opname in die Springbokspan, en so voort.

Kuyper en sy navolgers - in 1915 en later - sou egter nie met hierdie verabsolutering of skeeftrekking kon saamstem nie. Malan het hom soms van die uitskotte in die Boere-Calvinisme bedien, en die idee versterk van 'n suiwer blanke (nou ras- en nie volksgeoriënteerde) nasionale span, of later as 'n teenreaksie, ten minste soveel gekleurdes in die span.

Malan glo dat die owerheid geroepe is om regverdig teenoor die (hele) volk te wees. 'n Benaming wat hy telkens sonder uitklaring aan die volk as kultuurgemeenskap of die breër staatsvolk of samelewing verbind. Teenoor bogenoemde verabsolutering, voer neo-Calvinistiese denkers aan dat die owerheid teenoor alle kringe in die samelewing, waarvan een of meer volke of kulture in sy gebied 'n voorbeeld is, regverdig moet wees (Fowler 1988:28; Schippers 1959:141). 'n Staat kan teenoor meer as een taal- en kultuurgroep regverdig wees en met hulle 'n staatkundige eenheid vorm - soos die eertydse blanke Suid-Afrika met Afrikaans- en Engelssprekendes, België met Franse en Vlaamse kante en Switserland met sy Franse, Duitse en Italiaanse burgers (Malan 1959:47). Malan self het 'Afrikanervolkseenheid' én die politieke eenheid van Afrikaners en Engelse bepleit. ${ }^{8}$ Hy het gereformeerd geoordeel dat die 'erkenning van God' en nie die grille of wil van 'n bepaalde volk, staatsvolk of ras nie, die wortel is van wat gesond is in die 'volkslewe' (ook van die staatsvolk). Haal God uit die prentjie, en die 'volkslewe (ook van die staatsvolk) versink ... in die diepte van onverskilligheid en karakterloosheid' (Pienaar 1964:16). Verbind aan sy onderskeid tussen beginsel en toepassing, het 'n konsekwente

8 . By die kongres van die Nasionale Party op 19 September 1950, rig Malan hom ook tot die En kelssprek to 'n Eng 'n nasionale eenheid" (die woord ras is destyds ook vir " $n$ kultuurgroep gebruik) gebaseer op gelyke regte en 'ons eie Suid-Afrikaanse nasieskap'. Hierdie tweetalige nasie beskou hy as die draers van 'Suid-Afrika se volkslewe', sodat Malan se SuidAfrikaanse volk - of dan nasie - uit dié twee taalgroepe bestaan (Pienaar 1964:64). 
Calvinisme boonop daarvoor gesorg dat Malan van apartheid nie meer as 'n veranderlike metode maak nie (Pienaar 1964:13).

Malan sluit sy afskeidspreek af met die oortuiging dat 'ons én in ons volkslewe én in persoonlike handelinge die oog gevestig moet hou op die ere Gods ...' (Pienaar 1964:15-16). Scholtz sê op hierdie punt tereg dat Calviniste glo dat alle menslike handelinge tot eer van God in ooreenstemming met sy plan moet wees (Scholtz 1944:105). Geplaas in die tyd waarin hy leef, was Malan dus moontlik nie 'n Kuyperiaan nie, maar - tog - 'n neo-Calvinis in die breë sin van die woord. ${ }^{9}$

Wat die betekenis van dié skuif van D.F. Malan verhoog, is die steun wat hy daarvoor van predikante in die NG Kerk, Stellenbosse professore, president en mevrou Steyn, Generaal De Wet en 94 Rebelle uit die 'Centrale Gevangenis, Bloemfontein' en talle ander, gekry het (Booyens 1969:302306; Thom 1980:11). Wat hulle betref was Malan se skuif nie omstrede nie. Simpatiekgesindes kon sy afskeidspreek met waardering volg. Daarby was daar ook ondersteuners uit die ongeveer 20000 Boerebittereinders in die ABO - 'n groep wat 'n deurslaggewende rol in die nuwe NP, die Rebellie en die denkstroom van die Afrikaner in die eerste helfte of meer van die 19e eeu gespeel het. Dit was 'n groep met 'n sterk Christelik-nasionale houding, wat hulle konstant teen die ideologie van Britse imperialisme in verset sou bring. Twee kragte wat tot diep in die 20ste eeu sou bots (Strauss 2020b:4).

Ten opsigte van lewensbeskouing, beweer Scholtz tereg dat die NP grootliks mense was wat vanweë 'n 'sekere lewensbeskouing' polities saamgetrek het. Malan kon hom ook hierin bevind. Vir hom was politiek 'n 'heilige roeping' rondom die posisie van die Afrikaner as 'n sleutelfiguur in Suid-Afrika. Oortuigings waardeur hy opportunistiese Suid-Afrikaanse politici soos ene Tielman Roos, wat van die politiek '... 'n spel' gemaak het, toenemend geminag het (Koorts 2010:174; Scholtz 1944:258, 281).

\section{Malan en 'n historiese kerkvergadering}

As een van die 'jonger manne' sou Malan as predikant van die NG Kerk Graaff-Reinet gou raakgesien word. Voordat hy in Junie 1915 as die redakteur van die nuwe Hollands-Afrikaanse koerant, De Burger, in Kaapstad begin, verteenwordig hy die NG Kerk in 'n prominente rol by twee nuuswaardige gebeure.

Die eerste is toe hy 'n betekenisvolle rol in die NG Kerk speel in hulle poging om die Victoria-kollege op Stellenbosch as 'n volwaardige universiteit erken te kry. In 1916 word Stellenbosch deur wetgewing as 'n Hollands-Afrikaanse

9. Hierdie tipering word ook vir nie-Kuyperiane soos die Switserse Karl Barth gebruik wat ook as 'n neo-Calvinis bestempel is. Die VU-Potchefstroom-koers in die krisislyn (met neo-Calviniste binne en buite die GKSA), was nie die enigste 'soort' neo-Calviniste nie. Onder neo-Calviniste wêreldwyd kom soms diepgaande neo-Calviniste
verskille voor.
Universiteit erken. Malan ywer daarvoor vanweë sy gehegtheid aan sy kerk en sy teologiese opleiding, én sy eie mense of kultuurgroep (Booyens 1977:579).

Die tweede gebeurtenis is Malan se sleutelrol by die Federale Raad van NG Kerke. Hierdie Raad was destyds die mees algemeen verteenwoordigende meerdere vergadering ${ }^{10}$ in die NG Kerk, en die voorloper van die eerste Algemene Sinode van 1962. Die Raad het vanaf 27-29 Januarie 1915 in Bloemfontein vergader oor die Rebellie van 1914-1915 (NGK 1915:3-4). Die jong(-erige) Malan was een van die verteenwoordigers van die NG Kerk in Suid-Afrika (soos dié kerk in die Kaapprovinsie genoem is) in die vergadering van 30 lede (NGK 1915:3). Behalwe die sake wat sy lede (die NG sinodes in vier provinsies) op die agenda plaas, moes die Raad na die 'algemene belangen dezer Kerken' of NG sinodes omsien (Kleynhans sa:331). Die impak van die Rebellie op die NG Kerk - die emosies, bitterheid en verskeurdheid was in hierdie stadium van so 'n aard dat sy breedste vergadering eenvoudig daarop móés reageer. Daarom is 'n algemene konferensie van NG-predikante met die Raad van Kerke saamgeroep. Hierdie konferensie moes op die derde dag oorgaan na 'n raadsvergadering (Booyens 1969:279; NGK 1915:3). Die NG Kerk wou intern vinnig en wyd konsulteer voordat hy oor hierdie neteligheid onder Afrikaners - waarvan baie NG-lidmate was - praat. Skrywers oordeel dat dié vergadering van die Raad van Kerke een van die belangrikstes in die geskiedenis van die NG Kerk was. Die NG sinodes in die vier provinsies van Suid-Afrika én die Sinode van die GKSA en die Algemene Kerkvergadering van die Nederduitse Hervormde Kerk sou die besluite van die Raad in 1915 en 1916 ook goedkeur. Die invloed van die Raad van NG Kerke, met Malan as die aanvanklike formuleerder van die standpunte in Afrikaanse kerklike kringe, was groot op hierdie nasionale krisispunt.

In die Rebellie was dit hoofsaaklik Afrikaner teen Afrikaner: regeringstroep teen rebelse Afrikaner. Die eerste skote het op 27 Oktober 1914 by Rooiwal naby Pretoria geklap. Aan die begin van Februarie 1915 het die laaste rebelle by Upington oorgee. Aan rebellekant het 190 man gesneuwel en aan regeringskant 132. Die rebellie was 'n uitbarsting, swak voorberei en nie 'n weloorwoë inisiatief nie. Talle rebelle was ongewapen en sonder die nodige militêre toerusting. Teenoor ongeveer 11000 rebelle was daar ongeveer 30000 goed gewapende regeringsmanne (Scholtz 1941:206-210; Van Zyl Hattingh 2000:15, 78-79). Die Rebellie was 'n stryd van Afrikanernasionalisme teen 'n Suid-Afrikaanse regering met simpatie vir imperiale Brittanje in sy oorlog teen Duitsland (Wêreldoorlog 1 in 1914-1918) en dit wat as pro-Duitsland beskou is (Duitswes-Afrika, nou Namibië) (Giliomee 2012:288). So gesien, was die Rebellie 'n botsing tussen Afrikanernasionalisme en Britse imperialisme in sy laatmiddag of vroeë aandskemering.

10.In gereformeerde kerke dui die naam 'meerdere' bloot aan dat dit hier om meer gemeentes gaan wat deur hulle afgevaardigdes in ' $n$ vergadering saamkom. Dit gaan nie oor meer of hoër gesag nie, maar meer kerke of gemeentes as komplete kerke wat saam besluit. Hierdie Federale Raad was nie ' $n$ sinode wat bindende besluite vir die gemeentes en hulle sinodes kon neem nie, maar'n losser federale besluite vir die gemeentes en hulle sinodes kon neem nie, maar' $\mathrm{n}$ losser federale
byeenkoms, wat slegs adviserende besluite vir die hele NG Kerk neem (Kleynhans sa:331). 
Na aanleiding van 'n wenk van die afgetrede ds. Andrew Murray van Wellington, word ' $n$ leidraad vir die bespreking, plus konsepvoorstelle vir die Raad, vooraf opgestel. As gevolg van sy kerklik teologiese statuur, word D.F. Malan versoek om laasgenoemde gereed te kry. Later verhaal Malan (1959), wat bekend was vir sy deeglikheid en metodiese aanslag (Koorts 2014:134; Thom 1980:14), die uitvoering van hierdie versoek soos volg:

$[D]$ aar was geen tyd om te verloor nie. Stilte, ernstige bepeinsing en vertroue in die leiding van die Opperwese, in Wie se hand die lotgevalle van ons volk gerus het, was nou nodig. Daarvoor het ek die sandduine aan die bo-end van Die Strand gekies en ure daar deurgebring. Die konsepresolusies het ek daar opgestel. So is dit daarna aanvaar .... (bl. 27)

Met enkele kleiner wysigings en byvoegings, word Malan se voorstelle eventueel die besluite van die NG Kerk se Federale Raad van Kerke.

Die Raad betuig sy 'diepe smart' oor die wantroue en verbittering wat die gewapende stryd of verset teen die owerheid tussen volks- en geloofsgenote meegebring het. Christelike verdraagsaamheid en selfopoffering is by almal nodig. Die verwysing na laakbare optrede 'vooral bij alle leidslieden van ons volk', word geskrap omdat dit twyfel skep of die NG Kerk onpartydig is, en dalk die politieke verdeeldheid op die NG Kerk kan oordra. Tugklagtes teen rebelle of regeringsmense moet deur kerkrade hanteer word as die 'groot' oorlog verby is en die gemoedere gekalmeer het. Wet en orde moet in staat, kerk en gesinne gehandhaaf word, en verset teen die wettige owerheid moet op gewigtige, gegronde redes berus. Dit moet redes wees wat die toets van die Woord en Woordverligte gewetes deurstaan. Vrede sal nie herstel word indien verset teen die owerheid net met geweld teengegaan word nie. Die hele aangeleentheid vra 'n behoorlike ondersoek na die redes vir die verset, en moet deur bevoegde outoriteite regverdig en met inagneming van die 'volkswil' hanteer word (NGK 1915:17-19).

Aangevoor deur Malan, inisieer die Raad van Kerke versoening. 'n Versoeningsaksie waaruit almal met waardigheid kan kom en mekaar in die oë kan kyk. Tog lê daar 'n latente simpatie met die Rebellie in die formulering. Rebellie is, volgens die Raad, geoorloof as die redes vir die verset in die lig van die Woord begrond is. Die Raad spreek hom nie direk uit oor die meriete van die pas afgelope Rebellie nie, maar laat tog 'n deur vir verset oop. Daarby erken die Raad - weer in die lig van die Skrif - dat die owerheid wet en orde moet handhaaf. In dié proses laat hy hom deur Malan se kennis van die gereformeerde etiek lei, maar dit moedig uit ' $n$ kerklike oogpunt, ook sy strewe na volkseenheid tussen Christen-Afrikaners aan. Dit was gelowige Afrikaners wat later vir geslagte onder die verskeurdheid en wantroue wat deur die Rebellie veroorsaak is, gebuk moes gaan (Du Toit 2014:195; Scholtz 1941:277). Volkseenheid word deur Malan, by implikasie, aan die Boere-bittereindertradisie as 'n gemeenskaplike faktor of vertrekpunt in die Suid-Afrikaanse politiek van die eerste helfte van die 20 ste eeu verbind. Hierin bevind M.T. Steyn én die jong Nasionale Party hulle ook (Du Toit 2014:195; Malan se eie slotsom in Malan 1959:11-12; Scholtz 1941:277).

'n Relatief jong D.F. Malan het sy rol as 'n leidende NG en Christen-Afrikanerpredikant hier vertolk as tipies van Malan en aanvaarbaar vir die kerk. Dieselfde vergadering van die Raad aanvaar ook 'n voorstel van dr. Malan en ds. D.J. Pienaar, dat die NG Kerk naas sy algemene roeping ook 'n besondere roeping as kerk teenoor die 'Hollandschsprekend Afrikaner volk' het. Die NG Kerk moet 'nationaal' wees en waak oor 'onze' nasionale belange. Deur die NG Kerk moet die Afrikaner leer dat hy 'n roeping van God het vir die bevordering van sy eie geestelike, sedelike en stoflike vooruitgang. Die NG Kerk het 'n roeping ten opsigte van die koninkryk van God en die voortbestaan van die Afrikaner. Hy dien hierdie roeping deur buite die partypolitiek te bly, tensy godsdienstige of sedelike beginsels, of die belange van God se koninkryk op die spel is (NGK 1915:20). Twee merkers wat na Malan lei, sit in die mosie: die belange van die Afrikanervolk as 'n kultuurgemeenskap, én die tipies gereformeerde of neo-Calvinisties Kuyperiaanse samelewingsoptrede van die NG Kerk as kerk: die NG Kerk moet buite die partypolitiek bly, maar reageer as die geestelike kante van sake op die spel is. Malan sou inderdaad 'n pad kon loop met die neo-Calviniste van sy tyd (Strauss 2010:125-130)!

\section{Kultuur- en politieke eenheid uit innerlike oortuiging}

Daar vind ' $n$ koalisie (1933) en samesmelting (1934) tussen die NP (van die partyleier J.B.M. Hertzog) en die SuidAfrikaanse Party (SAP) (van partyleier J.C. Smuts) plaas. Hierdie samewerking en eventuele vereniging moes die prinsipiële kloof tussen Afrikanernasionalisme (NP) en 'n pro-Britse gesindheid (SAP) kunsmatig oplos. ${ }^{11}$ Te midde hiervan kom D.F. Malan as leier by die Kaaplandse kongres van die NP in Oktober 1933 met 'n spreuk. Hy wys koalisie en samesmelting af, maar bepleit die hereniging in die NP van hulle wat deur dieselfde politieke bril kyk: 'Hereniging beteken bymekaar bring wat deur politieke oortuiging bymekaar behoort ... dit verhinder die samesmelting van partye' (Booyens 1977:581).

Malan as 'n man wat hom vir kulturele en politieke Afrikanereenheid in sy lewenstrewe beywer het (Thom 1980:13), was oortuig dat koalisie en samesmelting in hierdie stadium nie sou slaag nie. Hertzog en Smuts verskil oor die deelbaarheid van die Britse kroon (die NP staan op die onafhanklikheid van die Unie van Suid-Afrika onder die Britse kroon), oor die reg van die Unie op neutraliteit indien Brittanje by 'n groter oorlog betrek word (in 1939 kies Hertzog neutraliteit vir die Unie in Wêreldoorlog II, terwyl Smuts die meerderheid in die Parlement oorhaal dat SuidAfrika oorlog teen Duitsland verklaar) en oor die soewerein onafhanklike status van die Unie (Booyens 1977:581).

11.Scholtz (1944:258) praat van " $n$ diep, onoorbrugbare lewensbeskoulike kloof tussen die NP en die SAP in 1934. 
Genoemde spreuk van Malan oor politieke oortuigings, loop dus saam met die meer algemene spreuk oor volksen politieke eenheid, waarvoor Malan bekend was: 'Bring bymekaar wat deur innerlike oortuiging bymekaar tuishoort' (Thom 1980:14).

Getrou aan homself, wou Malan 'n werkbare Afrikanereenheid en'n meer algemene politieke eenheid in Suid-Afrika tot stand bring, vanuit die wortel van die saak of lewensbeskouing dus vanuit innerlike oortuiging. Vir die politiek het hy 'n 'herenigingsbeweging' beoog wat bedoel om 'bymekaar te bring wat (eens) bymekaar was': 'n kulturele en politieke eenheid onder Afrikaners én 'n eenheid onder almal in die politiek, van watter taalgroep hulle ook al is, wat dieselfde grondoortuigings deel. Dit moes 'n eenheid tussen almal wees wat deur innerlike politieke oortuiging bymekaar kan uitkom. Beide vorme van eenheid moes op die fondament van "n vaste en gesonde beginselgrondslag' bou (Malan 1959:11-12; Thom 1980:15).

Tipies van onder meer die Calvinisme, is die demokratiese lyn ook in die Afrikaner se staatkundige tradisie opgeneem. ${ }^{12}$ Thom beweer dat 'die demokrasie regstreeks uit dr. Malan se verlede tot hom gekom' het. Sy Suid-Afrikaanse stamvader, Jacques Malan, het kwaai met landdros Starrenburgh, wat in Adam Tas se tyd in die begin van die 18e eeu gedienstig aan die korrupte, outokratiese goewerneur Willem Adriaan van der Stel was, gebots (De Villiers 2012:46). Nie net het die demokratiese trek in Malan hom van koalisie en samesmelting met Hertzog en Smuts weerhou nie, dit was ook 'n noodsaaklike voorwaarde vir die verwerkliking van sy spreuk: '... bring bymekaar wat deur innerlike oortuiging bymekaar tuishoort'. In 'n demokratiese bestel kon mense vanuit innerlike oortuiging vrylik met mekaar assosieer. So het Malan dikwels verklarings of toesprake wat hy sou lewer, eers aan lede van die redaksie van die Die Burger, vir hulle mening, voorgelê. As hy soms wel 'n mening kry wat hy nie kon aanvaar nie, het hy as 'n egte demokraat, nie gevoelens oorgehou nie (Thom 1980:16). ${ }^{13}$

Ook Malan se leierskap was van 'n demokratiese aard. Sy standpunt was: 'Ek glo in werklike leierskap, maar "leierskapin-rade"', of leierskap in lewende kontak met sy volk. As hy dan besluit het, het die uitvoering daarvan nie uitgebly nie. Vanuit hierdie demokratiese oortuiging, het D.F. Malan in die vroeë 1940's met die kommandant-generaal van die Ossewa-Brandwag, J.F.J. van Rensburg, gebots. Van Rensburg het, beïnvloed deur Hitler se nasionaal-sosialisme 'n 'Christelik-Nasionale Gesagstaat' voorgestaan. Malan het die swakhede van 'n demokrasie raakgesien soos in die Britse parlementêre stelsel by wie bestendigheid soms ontbreek het.

12.Van Schoor en Van Rooyen toon dat die 'eerste beslag' van 'n Afrikanerrepublikanisme in die Kaapkolonie in die laaste helfte van die $18 \mathrm{de}$ eeu, naas ' $n$ gereformeerd Calvinisties agtergrond, ook vanuit die humanistiese Nederlandse Patriottebeweging gevoed is. Uit laasgenoemde spruit die begrip van ' $n$ radikale demokrasie wat sentrale gesag met sterk uitvoerende regeerders van ' $\mathrm{n}$ radikale demokrasie wat sentrale isesag 'volksoewereiniteit' (Van Schoor \& Van Rooyen 1960:27-39).

13.Thom haal die oud-redakteur van Die Burger, dr. P.A. Weber aan, wat hierdie waarneming bevestig. Weber het verder gesê: ' ‘... ofskoon die mense van die pers geweet het dat dr. Malan nie ' $n$ vinnige denker is nie, het hulle ook geweet geweet het dat dr. Malan nie ' $n$ vinnige denker is nie, het hulle ook geweet
dat hy opregte belangstelling in hulle het, en dat hy bowenal weloorwoë is' dat hy opregte
(Thom 1980:16).
Tog het hy as 'n demokraat getoon dat hy 'n produk van sy land en herkoms was.

Hy het betoog: 'Dis daarom dat ons voorouers Protestante was en Geuse en Hugenote en Voortrekkers. Dis daarom dat ons 'n Afrikanervolk kon word. Dit sit in ons bloed' (in Pienaar 1964:42; vgl Thom 1980:18).

As Christen-Afrikanerwas D.F. Malan'n uitsproke voorstander van artikel 137 van die Suid-Afrikawet, of die grondwet van die Unie van 1910 (Van Schoor \& Van Rooyen 1960:171). Hierdie artikel oor die wetlike gelykheid van Nederlands en Engels in die nuwe Unie, is op aandrang van veral M.T. Steyn op die Nasionale Konvensie wat 'n grondwet moes opstel, aanvaar. Sy argument was die volgende: as Nederlands (of nou Hollands-Afrikaans) nie gelyk gestel word met Engels nie, was al die ellende van die $\mathrm{ABO}$ verniet ... En, in so 'n geval, sou Afrikaners uit die Unie kon onttrek (Giliomee 2003:276). Malan het hom in 1911 skerp uitgelaat oor die weiering van die Botha-Smutsregering om treine vir Afrikaanse studente op pad na die fees ter viering van artikel 137, beskikbaar te stel. Die fees sou kwansuis die Engelssprekendes ontstel. Malan se reaksie was dat die regering 'rassevrede (tussen Afrikaans en Engels) en vriendskap' daarmee van die tafel gevee het (Malan 1959:14). D.F. Malan was 'n spreker by die konferensie op Stellenbosch, waar hy volgens waarnemers 'besielend' oor taal en nasionaliteit gepraat het (Booyens 1977:578). Hy was oortuig daarvan dat indien 'n volk se taal en geskiedenis in 'n hoek gevee word, sy selfrespek en karakter daaronder sal lei (Koorts 2014:83). Vanuit sy lewensbeskouing en die daaruitspruitende beginsels, kon Malan hierdie gelykheid regverdig.

As Minister van Binnelandse Sake in die Paktregering van 1924, het Malan in 1925 'n amendement van die Grondwet deur die Parlement geloods, waardeur Afrikaans (in plaas van Nederlands) naas Engels as amptelike taal erken is. Die besluit is eenparig deur die Parlement aanvaar, en was die kroon op 'n lang gekoesterde ideaal van Malan. Sterk steun vir die Minister het van die bekende senator C.J. Langenhoven, 'n spitsvondige, bobaasgebruiker van Afrikaans uit die Klein Karoo, gekom. Malan sou tweetaligheid 'kragtig' in die staatsdiens deurvoer, en verbeterde geriewe en geldelike steun vir hoër en vakonderwys verkry. $\mathrm{Na}$ 'n stryd van ongeveer drie jaar kry Malan op 31 Mei 1928, 'n historiese dag vir Afrikaners, 'n Suid-Afrikaanse vlag waarin die nasieskap van die Afrikaanse sowel as die Engelse burgers weerspieël word. Getrou aan gelykheid en regverdigheid teenoor die Engelse en Afrikaanse deel in die blanke staatsvolk, sou Malan met so 'n Suid-Afrikaanse vlag deurdruk (Booyens 1977:580). Sy benadering was dat selfs die bestaan én ontwerp van die nuwe vlag op die innerlike oortuiging van die staatsvolk moes berus. Hierdeur word dit 'n voorbeeld van eenheid onder die staatsvolk.

\section{Kultuurvolk en staatsvolk}

Thom verwys na Malan se ywer vir sy kultuur- en staatsvolk (Thom 1980:41). 
'n Mens word aan jou kultuurvolk verbind deur taal, sedes en gewoontes. Dit is 'n algemene kultuur- of doenstyl waaraan jy jou vanweë herkoms en assosiasie, of net assosiasie, verbind. Dit is soos die wording van die Afrikanervolk na $1652 .{ }^{14}$ Dit maak deel uit van jou manier van doen in die staatsvolk en die politieke struktuur waarin jy jou bevind. Dit is ' $n$ eenheid wat aan verskillende kultuurgroepe een vaderland verskaf asook regte, soos taalregte, erken en toeken. Die burgers of kultuurgroepe van so 'n gemeenskaplike vaderland, maak die staatsvolk van daardie staat of land uit.

Volgens Thom is beide D.F. Malan se liefde vir sy volk en sy vaderlandsliefde gevoed deur' $n$ 'opregte godsdiensbewustheid ...' as 'voedingsbron vir ... kultuuruitinge' soos sy taal, opvoeding, volks-ennasionale verlede, onderlingeverhoudings, 'n rasgebondenheid en 'n rassuiwerheid - laasgenoemde twee fasette was 'n saak wat Malan dikwels geopper het (Thom 1980:15, 41). ${ }^{15}$

Kommentaar hierop is ter sake. Waar die hantering van veranderlike 'kultuuruitinge' in' $n$ proses van verChristeliking uit herbore of nuwe harte op die eer van God gerig moet wees, word ras konsekwent Christelik gesien, as 'n onveranderlike natuurgegewe beskou. Veranderlike 'kultuuruitinge' kan uit 'n Christelike beskouing verbeter en uitgebou en deur mense van buite aanvaar word, maar ras is onveranderlik en deur geboorte, 'n gegewe. Dit is 'n gegewe aspek wat nie 'n maatstaf of basis vir 'kultuuruitinge' kan of moet wees nie, want dan sal dit kunsmatig en gedwonge wees. Alle volks- en staatskultuur moet daarom voor die God van hemel en aarde (vgl die eerste reël van die Gelofte van 1838; Strauss 2001:824-825) prinsipeel en ten diepste Bybelsen nie rasbepaald wees nie. 'n Swart president kan in 'n bepaalde situasie vir die Verenigde State van Amerika ten opsigte van ' $n$ regering in algemene regsbelang ' $n$ beter opsie as 'n wit president wees, of omgekeerd. Dit gaan oor die persoon se vermoë, toerusting en lewensrigting en nie die ras of sosiale herkoms nie.

Reeds in 1918 pleit Malan dat elke selfstandige, mondige kultuurvolk die reg het om 'oor sy eie lot te beslis'. Die bevryding van 'n mondige volk, die Afrikaner, van 'n heerskappy waaronder hy nie wil lewe nie, is nie 'n guns van mense nie, maar 'n godgegewe, onvervreembare reg. Staatsmanne mag so onafhanklikheid verklaar, en dit het gewig omdat dit met goddellike gesag kom. Dit is deel van die 'ewige beginsels' van God vir reg en geregtigheid. Hierdie beginsels is deur Brittanje vertrap met sy imperialistiese oorlog teen die

14. Uit ' $n$ sensus in 1806 aan die Kaap, is vasgestel dat daar in daardie stadium 26720 blankes, 29256 slawe en 17657 Khoi-khoi was. Die Afrikaners is dus saamgestel uit $37 \%$ Nederlandse, $36 \%-37 \%$ Duitse en $12 \%$ Franse herkoms. Die Nederlanders (Van Rensburgs, Van der Merwes, Venters, ens.) en die Franse (Cilliers, Malans, De Villierse, ens.) sou uit 'n gereformeerde agtergrond kom, en die Duitsers (Strausse, Schreuders, Schwarze, ens.) uit 'n Lutherse agtergrond. Almal was egter Protestants, en deur hulle staatsbepaalde of verpligte saamwees in die NG Kerk aan die Kaap, mettertyd 'verplig' tot gereformeerd-wees (Strauss 2015:5).

15.In 1938 verklaar Malan dat die Voortrekker reeds, naas sy vryheidsideaal, ook die ideaal van rassuiwerheid en die heerskappy van die blanke ras in ' $n$ gees van reaal van rassum heilvan Suid-Afrik (Pientien heil van Suid-Afrika (Pienaar 1964:111-112). In 1941 sê Malan dat dit aan die NP te danke is dat die 'blanke beskawing, blanke arbeidsbeleid, ens. ...' in Suid-Afrika behoue gebly het (Pienaar 1964:39).
Boererepublieke in 1899-1902 - 'n oorlog waaroor die ganse wêreld 'diep verontwaardig gestaan het' (Pienaar 1964:23).

Met hierdie uitspraak ploeg Malan met die kalwers van sy vriend M.T. Steyn, wat op 28 November 1916 oorlede is (Van der Merwe 1921:5; Venter 2008:1049).

Ten opsigte van die sogenaamde 'blanke rasse' in die Unie, beywer Malan hom as Eerste Minister in 1950 vir 'ons eie SuidAfrikaanse nasieskap', gebaseer op die enigste gemeenskaplike grond daarvoor, naamlik gelyke regte. In die algemene verkiesing van 1953 en sy uittrede in 1954, kry Malan lof en steun van talle Engelssprekende Suid-Afrikaners vir hierdie standpunt (Thom 1980:54-55). In vae terme (hy gebruik 'n nie-relevante en agterhaalde term), vra hy in 1950 ook vir die openhartige erkenning en realistiese benadering van 'kleurverskille' in Suid-Afrika. So iets moet op 'n beleid bou van 'vrye ontwikkeling en regverdige behandeling aan beide kante van die skeidslyn' (Pienaar 1964:64). Malan kies wit voogdyskap, die erkenning van verskille en daarby skeiding met regverdigheid aan almal. Wat hom betref, kanselleer blanke voogdyskap nie altyd regverdigheid nie, inteendeel. Regverdigheid moet ook rekening hou met die konteks waarin maatreëls wat op algemene billikheid gerig is, gestalte kry.

In dieselfde Boerebittereindertradisie sou die verkryging van 'n republiek in Malan en die NP voortleef.

Ten opsigte van die toekoms van die blanke gemeenskap in Suid-Afrika, staan tweesake by Malan uit: dieonvervreembare reg om oor sy eie lot te besluit, én self die inkleding van die staat te bepaal. Vir Malan is albei 'n reg én 'n konstante beginsel. Wat hom betref, is die Unie se koppeling aan die Britse kroon ' $n$ omstrede kwessie. Hy is beslis nie aan Brittanje onderhorig omdat hy onder die kroon staan nie. Inteendeel, die Unie is onafhanklik onder die Britse kroon as sy eie kroon. Op hierdie punt aanvaar die Britse Rykskonferensie van 1926 in Londen die Balfourverklaring wat die visie van Malan bekragtig: die ryk bestaan uit selfregerende gemeenskappe of dominiums wat gelyk is in status en nie aan mekaar onderhorig is nie: in enige faset van binne- of buitelandse sake. Die konferensie bepaal dat hulle verenig is deur hulle gemeenskaplike trou aan die Britse kroon, maar 'vryelik verbonde (is) as lede van die Britse stategemeenskap' (Van Schoor \& Van Rooyen 1960:189).

$\mathrm{Na}$ die samesmelting in 1934, die opbloei van Afrikanernasionalisme met die Voortrekkereeufees in 1938 en politieke storms onder Afrikaners in 1939-1945, sou die strewe na 'n vrye republiek waarin hulle polities kultureel tuis voel, sterk by Afrikaners opleef (Scholtz 1944:283). Hierdie oplewing is ook by D.F. Malan sigbaar.

Onder sy leiding skryf die NP van Kaapland die republikeinse ideaal in 1937 in sy program van beginsels in. Hierdie ideaal word drie jaar later deur die Herenigde NP, of Volksparty wat uit die NP sou ontwikkel, oorgeneem. By die sogenaamde Krisiskongres op 3 Junie 1941 in Bloemfontein, word die ideaal herhaal. Op 13 Januarie 1942 stel Malan, as die leier van 
die opposisie, sy bekende republikeinse mosie in die Volksraad, omdat 'ons hoogste volksbelange alleen gedien kan word deur die omskepping van Suid-Afrika in 'n republiek'. Malan praat van 'n nuwe, gelukkiger toekoms en 'n heler van die land se wonde. Dit moet 'n republiek wees, afgeskei van die Britse Kroon en Ryk en onafhanklik van enige buitelandse mag. Hy beywer hom vir eenheid onder die staatsvolk, maar die 'Britse konneksie' en nie Suid-Afrikaanse belange nie, hou hulle uit mekaar. In sy beoogde republiek moet albei taalgroepe tuis voel, gewaarborg deur gelyke taalen kultuurregte (Thom 1980:19-20). D.F. Malan beklemtoon in sy mosie dat dit ' $n$ republiek moet wees wat geskoei is op ons 'eie ... aard en tradisies en die beginsels van volksregering' soos dit in die Transvaalse en Vrystaatse republieke voorgekom het. Sy beoogde Christelik-nasionale republiek moet aangepas word by moderne omstandighede, en dit wat skadelik is in die Britse liberale tradisie, moet nié oorgeneem word nie. Ook moet die 'blanke ras en sy beskawing ooreenkomstig die voogdyskap-beginsel' beveilig word (Malan 1959:97-98). Eventueel sou 'n gewysigde vorm van hierdie republiek op 31 Mei 1961 onder die NP tot stand kom (Scher 2012:339).

Met die kwessie van die 'beveiliging' van die blanke ras en sy 'beskawing', het Malan 'n groot probleem in Suid-Afrika aangesny (Thom 1980:249-251). Teen sy dood in 1959 was hierdie saak nog nie afgepraat en opgelos nie. Met 'n demokratiese Suid-Afrika en algemene stemreg in 1994, was 'blanke voogdyskap' en 'beskawing' nie meer op die politieke agenda van die hoofstroom in Suid-Afrika nie. Die begrip ras word 'n sensitiewe saak en swak dienslewering, onbevoegde regering, korrupsie en 'n worstelende rand ontwrig menseregte-bewuste Suid-Afrikaners - ook hulle wat menseregte Christelik begrond. Die voorgestelde oplossing van die Kerklike Kongres oor die Naturellevraagstuk van 1950 aan Malan as Eerste Minister, was totale territoriale gebiedsegregasie, gemik op die staatkundige onafhanklikheid en ekonomiese oorlewing van alle groepe - ook die swart volke. Malan het dit egter afgewys as iets wat nie prakties uitvoerbaar is nie. Daarmee is hierdie versoek van die tafel gevee. Segslui van die NG Kerk sou hierdie versoek in die jare daarna ook nie weer opvolg nie. Dit is slegs tydens Cottesloe in 1960 weer vermeld toe Verhoef hiermee wou sê: Daar is gevaar ${ }^{16}$ in die geleidelike mislukking van afsonderlike ontwikkeling soos dit onder Verwoerd bekend geword het. Hierdie mislukking is in 1985 deur president P.W. Botha erken en deur die vrylating van Nelson Mandela en die byeenroeping van Kodesa deur president F.W. de Klerk, toegegee (Koorts 2014:413; Strauss 1983:55-58).

Malan se oortuiging dat die begrippe blanke ras, blanke voogdyskap en beskawing gekoppel moet word en beslissende faktore vir die staat in 'n multikulturele Suid-Afrika is, het met die geleidelike stagnasie en sterwe van apartheid of afsonderlike ontwikkeling, sedert die 1970's uit die gesprek oor 'n oplossing verdwyn. Malan se formulering van en

16.As afgevaardigde van die Kaapse NG Kerk na die Cottesloeberaad van lidkerke van die Wêreldraad van Kerke in Suid-Afrika in 1960, sê Prof. P.A. Verhoef dat hulle weens kritiek op apartheid nie beleidsveranderings wou voorstel nie, maar die weens kritiek op apartheid nie beleidsveranderings wou voorstel nie, maar die
alarmklok wou lui om te sê: Daar is gevaar! Die beleid misluk in sy uitvoering alarmklok wou lui om te sê: Daar is gevaar! Die beleid misluk in sy uitvoering
(Persoonlike onderhoud met Strauss op 17 Oktober 1981; Strauss 1989:153). benaming apartheid (Booyens 1977:582; Strauss 1983:22, 27) $)^{17}$ is in hulle gebruik vir politieke strukture, na die politieke argiewe verban. Malan het wel erken dat hy nie 'n resep vir alle tye het nie, en dat die metode sal moet verander (Thom 1980:353). 'n Christelik-nasionale Afrikanerrepubliek ruik vir talle mense ook na apartheid, en dit word tans nie gepropageer nie. In plaas van apartheid, Malan se sleutel tot algemene geluk, word algemene geluk sedert 1996 in die Suid-Afrikaanse grondwet met sy akte van menseregte humanisties-indiwidualisties begrond, gesoek (Rautenbach \& Malherbe 1994:8-16; Strauss 2010:323). Hierdie akte is egter vir baie gewone mense ' $n$ saak wat in die klaskamer hoort, of die Suid-Afrikaanse howe (Rautenbach \& Malherbe 1994:3641: Judicial authority). Die kreeftegang van apartheid (Strauss 2020a:1-10) het ook twyfel in die lewensbeskouing van die ondersteuners van apartheid gebring: twyfel in Malan se Christelike lewensbeskouing en sy uitleef (die vrugte) daarvan. D.F. Malan se konsentrasie op Afrikaans, Afrikanervolkseenheid en die eenheid van die staatsvolk in die ou blanke Suid-Afrika, het hom moontlik genoop om die ras- en volkevraagstuk in Suid-Afrika tydelik agterweë te laat. Daarby het hy en die NP die druk om hierdie saak by die horings te pak en deurtastende geprekke en planne met almal daaroor aan te pak, weerstaan.

\section{Slot}

D.F. Malan se geduld, sistematiese denke en goed deurdagte standpunte, asook sy eerlikheid en diep Christelike oortuigings, sy roeping, sy slag met skares as 'n klassieke redenaar en 'n begrip vir sy mense, het meegebring dat hy vir byna 40 jaar onafgebroke 'n leiersposisie in die Afrikaneren Suid-Afrikaanse politiek beklee het. Nadat hy die kansel in 1915 vir die politieke kateder verruil het, moes hy homself ingrawe in daardie sake wat hom na aan die hart gelê en leiersinsette nodig gehad het: Afrikaans, Afrikanereenheid, 'n Afrikaner-Engelssprekende staatsvolk en politieke selfvertroue by Afrikaners. Hy het as 'n onervare predikant op hierdie terrein nie net die redakteur van 'n nuwe Hollands-Afrikaanse dagblad, De Burger, geword nie, maar moes dadelik voorvat as die leier van die NP in Kaapland. Die feit dat albei hierdie take in 'n spanningsvolle tyd aan hom toevertrou is, getuig van die vertroue van medeAfrikaners in sy vermoë om as 'n volks- en gemeenskapsleier op te tree.

Begenadig met 'n Christelik Calvinistiese lewensbeskouing, het Malan vir die hantering van elke saak beginsels ontwikkel wat in hulle uitvoering 'ongeskonde' of konstant moes bly. Beginsels wat die metodes en prosedure vir die uitvoering daarvan moes bepaal. Hierdie benadering het hom in staat gestel om spreuke vir optrede in die gemeenskap te ontwikkel wat die verbeelding aangegryp, en in veranderde tye dieselfde gebly het. Die bekendste spreuke is: Bring bymekaar wat deur innerlike oortuiging by mekaar tuishoort, asook Glo in God, glo in jou volk, glo in jouself.

17. Malan en die NP het die verkiesing van 1948 met die slagspreuk van apartheid gewen, alhoewel hy nie die eerste openbare figuur was wat die term gebruik het nie. As term was apartheid teen hierdie tyd ' $n$ vervanger van die woord segregasie en 'n positiewe woord onder Afrikaners (Strauss 1983:22; Thom 1980:274). 
Die onderskeid tussen beginsel en metode en sy oortuiging dat apartheid ' $n$ metode was, het Malan gelei om te aanvaar dat die beleid nie staties kan of mag wees nie.

Malan het reeds in sy tyd as politikus vanaf 1915-1954 en Eerste Minister gedurende 1948-1954, die vrug van sy arbeid geproe. Kultureel gesproke was die Afrikaners verenig en met die algemene verkiesing van 1953 kon die NP sy meerderheid van stemme as regeringsparty vergroot. Meer Engelssprekendes het hom ondersteun. Sy ywer vir 'n verenigde kultuurvolk en groter eenheid onder die staatsvolk, gebaseer op sekere gemeenskaplike oortuigings, het vrug opgelewer.

Ten opsigte van die totale volkereverskeidenheid in SuidAfrika, het Malan nie by 'n oplossing uitgekom nie. Hy wou blanke voogdyskap én algemene regverdigheid handhaaf, maar kon die verwerkliking van totale gebiedsegregasie sonder ' $n$ plafon op die ontwikkeling by almal, nie prakties visualiseer nie. Malan is die Eerste Minister van Suid-Afrika en leier van die $\mathrm{NP}$ aan wie die term apartheid wêreldwyd verbind is.

\section{Erkennings \\ Mededingende belange}

Die skrywer verklaar dat hy geen finansiële of persoonlike verbintenis het met enige party wat hom nadelig kon beïnvloed in die skryf van hierdie artikel nie.

\section{Outeursbydrae}

P.J.S. was die enigste skrywer van hierdie artikel.

\section{Etiese oorwegings}

Hierdie artikel volg alle etiese standaarde vir navorsing sonder direkte kontak met mens of dier.

\section{Befondsing}

Hierdie navorsing het geen spesifieke toekenning ontvang van enige befondsingsagentskap in die openbare, kommersiële of nie-winsgewende sektore nie.

\section{Databeskikbaarheid}

Data-deling is nie van toepassing op hierdie artikel nie, aangesien geen nuwe data geskep of ontleed is nie.

\section{Vrywaring}

Die sienings en menings wat in hierdie artikel uitgedruk word, is dié van die skrywer en weerspieël nie noodwendig die amptelike beleid of posisie van enige geaffilieerde agentskap van die skrywer nie.

\section{Bronnelys}

Booyens, B., 1969, Die lewe van D.F. Malan - die eerste veertig jaar, Tafelberg, Kaapstad. Booyens, B., 1977, Malan Daniël Francois, SA Biografiese Woordeboek III, bl. 577-585, Tafelberg, Kaapstad.

De Jongh, P.S., 1987, Sarel Cilliers, Perskor, Johannesburg.

De Villiers, J., 2012, 'Die Nederlandse era aan die Kaap 1652-1806', in F. Pretorius (red.), Geskiedenis van Suid-Afrika van voortye tot vandag, bl. 39-62, Tafelberg, Kaapstad.

Du Toit, F., 2014, 'Die Afrikaanse Kerke en die Rebellie', in D. Langner \& A. Raath (red.), Die Afrikanerrebellie 1914-1915, bl. 195-246, Kraal, Pretoria.

Fowler, S., 1988, The state in the light of the Scriptures, PU vir CHO, Potchefstroon.

Giliomee, H., 2003, The Afrikaners - Biography of a people, Tafelberg, Kaapstad.

Giliomee, H., 2012, 'Afrikanernasionalisme 1902-1924', in F. Pretorius (red.), Geskiedenis van Suid-Afrika van voortye tot vandag, bl. 275-292, Tafelberg, Kaapstad.

Kleynhans, E.P.J., s.a., Die kerkregtelike ontwikkeling van die Nederduitse Gereformeerde Kerk in Suid-Afrika, s.n., s.I.

Koorts, L., 2014, DF Malan en die opkoms van Afrikanernasionalisme, Tafelberg, Kaapstad.

Malan, D.F., 1959, Afrikanervolkseenheid en my ervarings op die pad daarheen, Nasionale Boekhandel, Kaapstad.

NG Kerken in Zuid-Afrika, 1915, Handelingen van eene buitengewone vergadering van den Raad der Ned. Ger. Kerken in Zuid-Afrika, Paarl Drukpers, Paarl.

Odendaal, B.J., 1957, Die kerklike betrekkinge tussen die Suid-Afrika en Nederland (1652-1952), Wever, Franeker.

Pienaar, S.W., 1964, Glo in u volk - D.F. Malan as redenaar, Tafelberg, Kaapstad.

Raath, A.W.G., 2012, Onthou, Kraal, Brandfort.

Rautenbach, I.M. \& Malherbe, E.F.J., 1994, What does the constitution say?, RAU, Johannesburg.

Reynolds, C., 2013, Konsentrasiekampsterftes gedurende die Anglo-Boereoorlog 1899-1902, Kraal, Brandfort.

Scher, D.M., 2012, 'Die vestiging van die apartheidstaat 1948-1949', in F. Pretorius (red.), Geskiedenis van Suid-Afrika van voortye tot vandag, bl. 425-344, Tafelberg, Kaapstad.

Schippers, R., 1959, Johannes Calvijn, Kok, Kampen.

Scholtz, G.D., 1941, Generaal Christiaan Frederik Beyers 1869-1914, Voortrekkerpers, Johannesburg.

Scholtz, G.D., 1944, Dr. Nicolaas Johannes van der Merwe 1888-1940, Voortrekkerpers, Johannesburg.

Strauss, P.J., 1983, Die Nederduitse Gereformeerde Kerk en die Gereformeerde Kerke in Nederland: Betrekkinge rondom die Suid-Afrikaanse rassevraagstuk, UP ongepubliseerde DD-proefskrif, Pretoria.

Strauss, P.J., 1989, 'Ekumene gestol?', in J.A. du Rand \& J.S. Kellerman (eds.) Diensknegte van die Koning, bl. 146-162, Pro Christo, Bloemfontein.

Strauss, P.J., 1994, 'Die Algemene Sinode van 1966 van die NG Kerk en apartheid', Studia Historiae Ecclesiastica 20, 3, 195-214.

Strauss, P.J., 2001, 'Nogeens: Die agtergrond, inhoud en implikasies van die Gelofte van 1838', Hervormde Teologiese Studies 57, 3(4), 824-834. https://doi. org/10.4102/hts.v57i3/4.1849

Strauss, P.J., 2008, 'Calvyn, Johannes', in F. Gaum (hoofred.), Christelike Kernensiklopedie, bl. 157-159, Lux Verbi, Wellington.

Strauss, P.J., 2010, Kerk en orde vandag, Sunmedia, Bloemfontein.

Strauss, P.J., 2015, Gereformeerdes onder die Suiderkruis 1652-2011, Sunmedia, Bloemfontein.

Strauss, P.J., 2020a, 'Die Nederduitse Gereformeerde Kerk se afskeid van apartheid: Cottesloe (1960) 'n voorloper van 'Kerk en samelewing' $(1986,1990)$ ?', In die Skriflig 55(1), a2529. https://doi.org/10.4102/ids.v54il.2529

Strauss, P.J., 2020b, M.T. Steyn: 'n Moderne Christen-Afrikanerleier? Ongepubliseer.

Strauss, P.J., 2021, 'Gelofte bind deur oortuiging', Volksblad, 15 Januarie 2021, bl. 8.

Thom, H.B., 1980, D.F. Malan, Tafelberg, Kaapstad.

Van der Merwe, N.J., 1921, Marthinus Theunis Steyn, deel 2, Nasionale Pers, Kaapstad.

Van Schoor, M.C.E., 1993, Die Nasionale Vrouemonument, Oorlogsmuseum van die Boererepublieke, Bloemfontein.

Van Schoor, M.C.E. \& Van Rooyen, J.J., 1960, Republieke en republikeine, Nasionale Boekhandel, Bloemfontein.

Van Zyl Hattingh, P.J., 2000, Die Rebellie: My tog deur die woestyn na Duitswes, Oorlogsmuseum van die Boererepublieke, Bloemfontein.

Venter, C., 2008, 'Marthinus Theunis Steyn (1857-1916)', in F. Gaum (hoofred.), Christelike Kernensiklopedie, bl. 1 049-1 050, Lux Verbi, Wellington. 